\title{
H1-1 wt Allele
}

National Cancer Institute

\section{Source}

National Cancer Institute. H1-1 wt Allele. NCI Thesaurus. Code C126424.

Human H1-1 wild-type allele is located in the vicinity of $6 \mathrm{p} 21.3$ and is approximately $1 \mathrm{~kb}$ in length. This allele, which encodes histone $\mathrm{H} 1.1$ protein, plays a role in the formation of nucleosomes and higher-order chromatin structures. 